\title{
NOTES ON THE 6TH SOUTH AFRICAN ARMOURED DIVISION POSTAL UNIT*
}

\section{a. BRIEF MILITARY HISTORICAL OUTLINE}

1. In February, 1943 the nucleus of the 6th South African Armoured Division was stationed at Premier Mine, Transvaal. From then onwards units which eventually were to become part of the Division, joined this nucleus from various parts of the country.

2. The majority of the units came from the Mediterranean Fighting Forces (M.F.F.), which, with Headquarters at Ermelo, Transvaal, had brigade formations at Piet Retief and Barberton-Carolina, also in the Transvaal.

3. The Postal Unit of the Division drew personnel from the M.F.F. and the balance were sent from Base Army Post Office, Durban.

4. Upon arrival, personnel were required to sign the oath volunteering for service anywhere and had to be of a medical category not lower than BI. The postal staff were immediately utilised to assist at the Premier Mine Camp Post Office.

5. In March-April, 1943 the Division was moved to Hay Paddock Camp, Pietermaritzburg where, after some weeks of waiting, embarkation became a reality. In the middle of April two convoys conveying the division set sail for the Middle East.

6. The final delivery of mail on board ship was effected the day after sailing. Early on, during the journey, all postal non-commissioned officers were called together and instructed in the nature of their duties and the Army Post Office (A.P.O.) personnel were given lectures on postal requirements in the field.

7. After đisembarkation at Suez, troops were transported by rail to Khatatba, which was to become the postal unit's home for many months to come. This was the unit's first real experience of the desert, and for many, the first opportunity of performing postal duties in the field. It did not take long, however, to get organised. Postal non-commissioned officers co-operated fully and, with the bulk of the business being transacted in the mornings, the afternoons were free for sport and other recreational activities.

8. Air mails from South Africa were being conveyed on the bi-weekly flying boat from Durban, and were usually available for distribution on Sundays and Wednesdays. The service was regular and efficient, and in no small way contributed to the high morale of the thousands of men required to carry out arduous and often monotonous training programmes. There were occasions, however, when the flying boat was late, owing mainly to adverse weather conditions en route.

9. Sport in those days played no small part in maintaining the morale and health of the troops. The Army Postal unit was one of the most enthusiastic units in the division, and notwithstanding a small staff to select from, nevertheless acquitted itself creditably on the sports fields. The captain of the soccer side was an enthusiastic N.C.O., whose boundless energy, resulted in his well-known team taking on all comers, mostly during the evenings. Most memorable of all the games were the hard fought matches against the Kiwis, in regard to which enthusiasm was kept at a high pitch by, in particular, the provocative articles of "Exile" in the Egyptian

* The information which follows has been extracted from the unit's historical records of which the authorship is unknown. 
Mail, which led to contests in many other types of sports being organised. Here the "Springboks" established and maintained unenviable records on the sports fields, which were later to be matched and surpassed on the fields of battle.

10. During this preparatory period, a single Army Post Office, located at Divisional Headquarters, was serving the whole division. This was the most practical arrangement, in view of the concentration of all units in such a small area. In December, 1943 it was, however, considered advisable to split up and establish Brigade offices, in order to give the personnel an opportunity of simulating operational conditions to ensure that the best possible service would be rendered when the Division really became involved in battle.

11. In January, 1944 the Division moved to Helwan, from where it was again moved to the Central Mediterranean Forces (C.M.F.) during April, 1944.

12. In Southern Italy, Divisional Headquarters was originally located at Altamura, with 11th and 12th South African Brigades at Matera and Gravina respectively. Army Post Office (A.P.O.) 44, which had moved over with the advance party, was closed on the arrival of A.P.O. 5 which itself ceased to operate from Divisional Headquarters and moved to "Q" harbour area.

13. 12th Brigade was the first to become operational, and moved up to Fornelli in support of a Kiwi Division under command of 10th Corps. Thereafter the Division Headquarters and the 11th Brigade moved up to the Caserta area, from where, upon being rejoined by 12th Brigade, they moved up to an area known as "Cox's Corner" on Route 6, a little distance south of Cassino. Some difficulty was temporarily experienced in maintaining regular contact with the Brigade's A.P.O.'s, as the area was very congested with innumerable convoys, and as all major movements were governed by a system of one way routes. On one occasion an N.C.O. and a driver set out to locate a Brigade office and after three hours of driving saw a welcome A.P.O. signboard. On stopping, however, they realised that they had landed back at the office from which they had originally set out. The Division's A.P.O. continued to be located in the "Q" harbour area, with Brigade A.P.O.'s at the Brigade echelons. A.P.O. 13 at Reserve Group Headquarters meantime remained at Torrito, near Bari.

14. Movement from this time onwards were very rapid, and stops in excess of forty-eight hours were exceptional. Command changed from the first Canadian Corps to 13th Corps after Ferentino (Frosinone). A parting gift from the Canadian Corps was the unexpected arrival at 0300 hours of six three-tonners of surface mail when everything had been packed in readiness for the convoy to move at 0500 hours. The bags were hastily off-loaded and placed under guard, with a fervent prayer that it would not rain. The stack was subsequently cleared without loss of a single item.

15. Soon the capital city of Italy, Rome, was in allied hands, with the enemy retreating towards the Appenines while making full use of the country, using all manner of delaying tactics and fighting bitter rearguard actions. At this stage our armour was brought into full use with great success. At Civita Castellana, the "Q" convoy was shelled, as was the harbour area. The Brigade's echelon areas were also frequently harassed by shelling but fortunately without suffering any casualties to A.P.O. personnel. A greater danger at that time was from mines cleverly laid in innocent looking fields and vineyards. A.P.O. 12 had a lucky escape at one stage. The driver did not like the area allocated, so sought permission to park elsewhere. The next vehicle that moved into the original site was blown to bits. 
16. In July, 1944, while at Chuisi, the Director, Lt.-Col. G. A. Leech, O.B.E., M.M., and the Assistant Director, Lt.-Col. A. B. McDonald, arrived in the Divisional Area on an inspection tour. In a crowded week all units and formations were visited and during the personal contacts made with heads of sections, formations and unit commands, it was confirmed that the service was functioning efficiently and satisfactorily. A general demand for postal orders and a proposal that a daily shuttle service should be allocated for air mails from South Africa, subsequently resulted in the introduction of these additional services.

17. On 7 August, 1944, the Division was taken out of the line, and units were camped in the area of Sienna-Radda-Castelnuova for a period of rest.

18. On 24 August, 1944 there was a regrouping in the Castelfiorentino area prior to the assault on Florence. Command was changed from 8th to 5th Army, operations only being directed by the American Second Corps, with the Administrative and Supply side still under the 13th Corps. Subsequently when 13 Corps moved over to the Adriatic sector, a British element with the 5th Army controlled the AQ side.

19. In September, 1944 the Arno was crossed and October saw the move into the Prato areal at the foot of the Appenines. This was to be the home of the B echelons for some six months, and with the approach of winter, troops were, wherever possible, moved into billets. A.P.O.'s operated in a textile factory, with A.P.O. 11 and A.P.O. 12 operating in suitable accommodation in their areas. Reserve Group had, in July, moved up from Bari to Alife, near Caserta, and in December, 1944 to Montevarchi, south of Florence.

20. In February, 1945 A.P.O. 37 was opened to serve the newly formed 13 South African Motorized Brigade. The Division also came out of the line, and on 23 February, 1945 A.P.O.'s 11 and 12 were amalgamated to serve troops in the Lucca area. Service installations, however, remained at Prato and 13 South African Brigade at Pistoia.

21. At the beginning of April, the Division moved back into the line preparatory to the final break through. The Brigade's A.P.O.'s moved up gradually with the B echelons, but A.P.O.'s remained at Prato until 23 April, 1945 when a single move to San Giovanni, north of Bologna, was made.

22. Thereafter communications became disrupted on account of the rapid advance on all fronts. Some delays were occasioned on account of the great distances between the forward formations and the divisional maintenance areas, and sometimes through inability to procure the necessary transport during moves.

23. After crossing the River Po the division bypassed Padua towards Trevisio, to be diverted at short notice to the Milan area.

24. After the cessation of hostilities, A.P.O. 5 rejoined Divisional Headquarters at Monza. G.P.O.'s 11 and 12 were closed, as was A.P.O. 13 at the end of May, 1945, with the absorbtion of the Reserve Group into the Division. Is was decided then to close all possible offices in order to release personnel for return to South Africa. This was not, however, immediately practicable with 13 South African Brigade at Turin. After the Divisional Headquarters had moved from Vercelli, 12 Brigade moved to Aosta and A.P.O. 12 had to be reopened. With the amalgamation in July, 1945 of 12 and 13 South African Brigades, G.P.O. 12 closed at Aosta, and reopened to Genoa to serve the Divisional Equipment Park and other units in that area. 
25. In October, 1945 the Division moved to the coastal area, and it was then possible to close A.P.O.'s 12 and 37 and keep A.P.O. 5 to serve the Division.

\section{b. LAY-OUT AND MODUS OPERANDI}

1. The three-ton vehicles used by the postal service were fitted internally with cupboards, tables and sorting frames. These were normally static vehicles, except where the post office was accommodated in a billet, and independent transport was used for the carriage of mails.

2. At A.P.O.'s, (the Divisional office) two three-ton vehicles would be parked approximately three meters apart, with penthouse attachments on the outsides and a tarpaulin slung between the two to form a central covered space. The chief consideration was protection from the elements in rainy weather. It remains a proud record of the service that at no time was any mail damaged through exposure to rain or mud.

3. All divisional mails were collected from the Corps $T$ office and brigade mails from the divisional office. In the case of air mails, direct clearance by the divisional office from the airfield was generally effected.

4. The first forward airfield to be used in Italy was Littona, Rome. Thereafter, as the advance continued, Orvieto, Castiglione (Lake Transimeno), Cecina, Pisa and Florence airfields came into use.

5. Not infrequently, owing to bad flying conditions, mails were carried by the road service to and from Naples, which was normally regular and dependable. It was for the purpose of collection of air mails that jeeps were included on the postal unit establishment. After the break through in the Appenines, the existing 8th Army air service from Forli was temporarily utilised until airfields were established at Bologna, then Verona and finally Milan.

5. Large consignments of surface mails were collected from railhead. The system was for each unit to provide sufficient transport to clear the mails direct. Mails for smaller units and various miscellaneous bags were generally carried in " $Q$ " transport, and handled at the individual office concerned.

6. During static periods, there was direct vouching between bases and all divisional offices, but during operations, owing to the frequent changes in the locations of units, all mail was concentrated on A.P.O.'s from where distribution to the Brigade offices was effected. All outgoing mail was sorted down into as many selections as practicable to facilitate handling at bases.

7. Main stocks of stamps and postal orders were held at A.P.O. 5 where requisitions from Brigade offices were met.

8. Throughout the campaign, it was necessary to maintain close contact with the Deputy Assistant Director of Army Postal Services (D.A.D.A.P.S.) at Corps Headquarters and the Assistant Director Army Postal Services (A.D.A.P.S.) at Army Headquarters.

\section{c. GENERAL}

1. Sufficient praise cannot be extended to the personnel of the British Postal Services in the field who were at all times of great assistance and whose co-operation in no small measure ensured the efficient handling of our mails. 
2. A further noteworthy feature was the keenness and co-operation shown by the South African regimental and unit postal non-commissioned officers. Most of these men had been employed on postal duties since the inauguration of the division, and were accordingly fully conversant with their duties. During the winter months in Italy many had to travel long distances daily, in bitter weather, with a regularity that was uncanny and without any complaint, which testifies to their dedication to the postal service which in turn did much to ensure the high morale and fighting standard of the 6th S.A. Armoured Division.

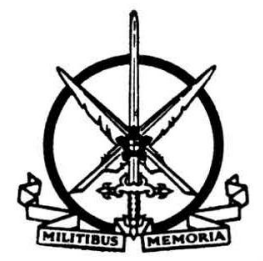




\section{LIST OF ABBREVIATIONS}

A.P.O. - Army Post Office.

Armd. Bde. - Armoured Brigade.

B.N.A.F. - British Naval Auxiliary Forces.

C.M.F. - Central Mediterannean Forces.

Coy. - Company.

D.A.D.A.P.S. - Deputy Assistant Director of Army Postal Services.

D.D.A.P.S. - Deputy Director of Army Postal Services.

D.R.L.S. - Despatch Rider Line Service.

G.H.Q. - General Headquarters.

G.O.C. - General Officer Commanding.

L. of C. - Lines of Communication.

M.E.F. - Middle East Forces.

Motd. Bde. - Motorised Brigade.

M.T.B. - Motor Torpedo Boat.

P.O. - Post Office.

P.O.W. - Prisoner of war.

O.C. - Officer Commanding.

O.S.C. - Officers Commanding.

Q.M.G. - Quartermaster General.

R.D.L.I. - Royal Durban Light Infantry.

S.A.A.F. - South African Air Force.

S.A.A.P.C. - South African Army Postal Corps.

S.A.A.P.O. — South African Army Post Office.

S.A.E.C. - South African Engineer Corps.

S.A.G.H. - South African General Hospital.

U.D.F. - Union Defence Force. 